\title{
Geology of an Alpine-Type Peridotite in the Mount Sorenson Area, East-Central Alaska
}

GEOLOGICAL SURVEY PROFESSIONAL PAPER 1170 -A 


\section{Geology of an Alpine-Type Peridotite in the Mount Sorenson Area, East-Central Alaska}

By TERRY E. C. KEITH, HELEN L. FOSTER, ROBERT L. FOSTER, E. V. POST, and W. L. LEHMBECK

SHORTER CONTRIBUTIONS TO GENERAL GEOLOGY GEOLOGICAL SURVEY PROFESSIONAL PAPER $1170-$ A

A petrologic and structural study of a large ultramafic body in the

Yukon-Tanana Upland 


\title{
UNITED STATES DEPARTMENT OF THE INTERIOR \\ JAMES G. WATT, Secretary
}

\author{
GEOLOGICAL SURVEY
}

Doyle G. Frederick, Acting Director

Keith, Terry E. C.

Geology of an alpine-type peridotite in the Mount Sorenson area, east-central Alaska.

(Shorter contributions to general geology) (Geological Survey Professional Paper; 1170-A)

Bibliography: p. A9.

Supt. of Docs. no.: I $19.16: 1170-A$

1. Peridotite--Alaska--Sorenson, Mount, region. I. Keith, Terry E. C. II. Series. III. Series: Geological Survey Professional Paper; 1170-A. QE462.P45G46 552'.3 


\section{CONTENTS}

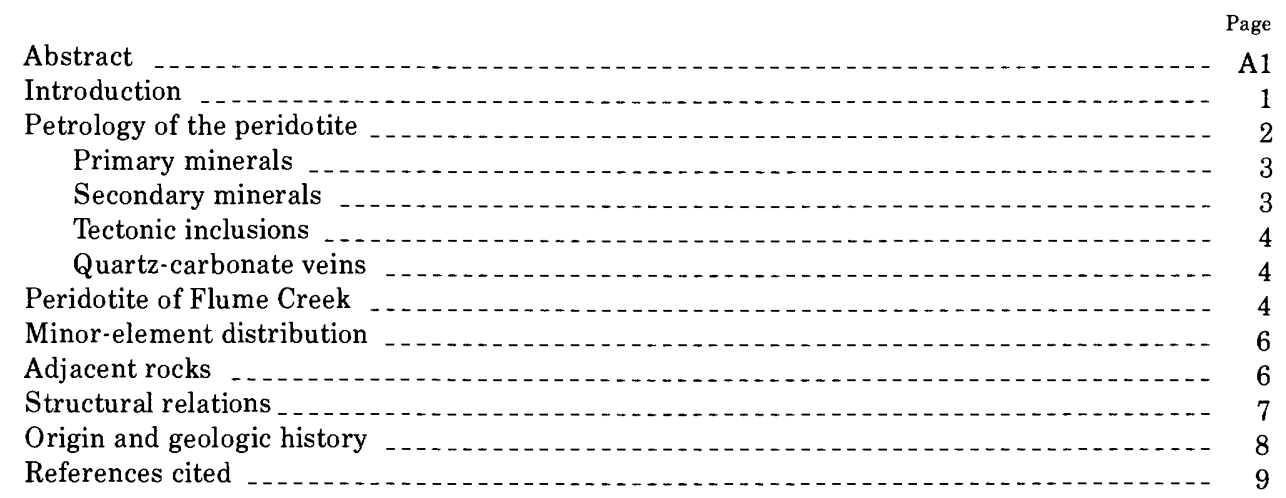

\section{ILLUSTRATIONS}

FiguRES 1-4. Maps showing:

1. Location of areas which include peridotites of Mount Sorenson and Flume Creek, Alaska

2. Geology of the peridotite of Mount Sorenson

3. Geology of the peridotite of Flume Creek

4. Aeromagnetic contours of Mount Sorenson area

\section{TABLE}

TABLE 1. Semiquantitative spectrographic analyses of ultramafic rocks from the serpentinized peridotites of the Mount Sorenson and Flume Creek areas 



\title{
GEOLOGY OF AN ALPINE-TYPE PERIDOTITE IN THE MOUNT SORENSON AREA, EAST-CENTRAL ALASKA
}

\author{
By Terry E. C. Keith, Heilen L. Foster, Robert L. Foster, ${ }^{1}$ E. V. Post, ${ }^{2}$ and W. L. Lehmbeck
}

\begin{abstract}
An alpine-type peridotite of the harzburgite subtype, about $47 \mathrm{~km}^{2}$ in area, crops out in the vicinity of Mount Sorenson in the Eagle and Charley River quadrangles of east-central Alaska. The peridotite consists mainly of harzburgite, some dunite, and minor clinopyroxenite. All of the peridotite has been serpentinized to some extent, most extensively in the eastern part. Lizardite is the dominant serpentine mineral. Large tectonic inclusions of diabase have been altered, probably by metasomatism during serpentinization. Four small quartz-carbonate veins are also included. The peridotite crops out as a synform mass trending nearly east-west. Aeromagnetic contours closely follow the configuration of the outcrop. The rocks surrounding the peridotite include greenstone, metamorphosed basalt and gabbro, quartzite, mica-schist, greenschist, chert, phyllite, and other metamorphosed rocks of probable Paleozoic age. The ultramafic rocks are believed to have been tectonically emplaced and may be part of a dismembered ophiolite. The nearby Tintina fault, a major fault system with significant, right-lateral displacement, may have been a deep suture along which mantle material was derived and obducted onto a slice of northwestward-moving continental crust.
\end{abstract}

\section{INTRODUCTION}

A large serpentinized peridotite body, about $47 \mathrm{~km}^{2}$, crops out in the northeastern Eagle and the southwestern Charley River 1:250,000 quadrangles in the Yukon-Tanana Upland of east-central Alaska (fig. l). Because it includes part of Mount Sorenson, the most prominent landmark of the area, the rocks of this peridotite body are referred to as the peridotite of Mount Sorenson.

The Yukon-Tanana Upland ( called the Yukon crystalline terrane by Tempelman-Kluit, 1976, p. 1343 where it extends into Canada) is an area of greenschist- to amphibolite-facies metamorphic rocks that have been intruded by Mesozoic and Tertiary granitic rocks (Foster, 1976). The peridotite body crops out as a synform mass trending nearly east-west and having two limbs, a northern limb about $30 \mathrm{~km}$ long and a southern limb 14

'Cache Creek Exploration Company, Reno. Nevada.

'Skyline Labs., Inc., Wheat Ridge, Colo.

'Hawley and Hawley Assayers and Chemists (Division Skyline Labs., Inc. ), Tucson. Ariz.

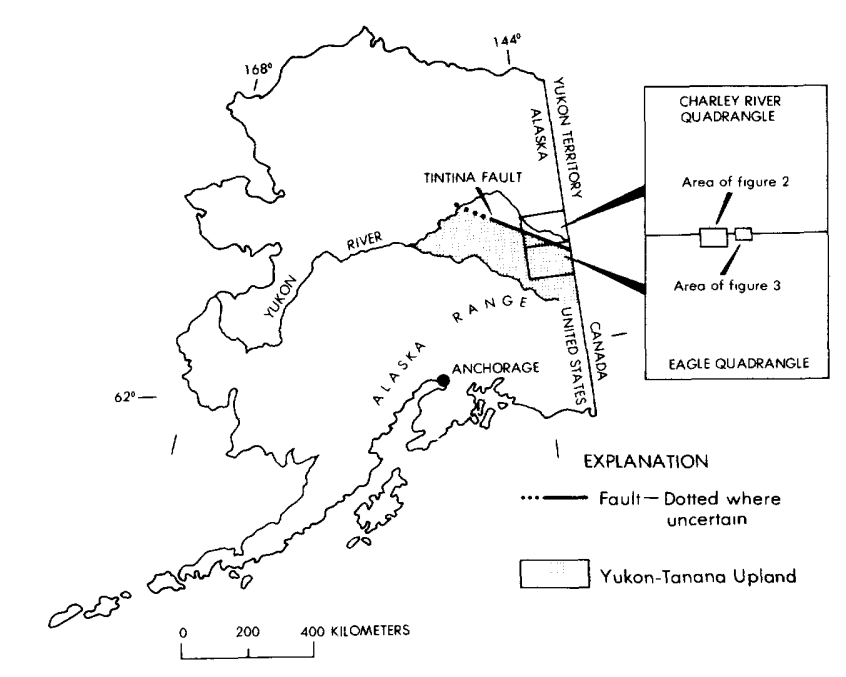

Figure l.-Location of map areas that include peridotites of Mount Sorenson and Flume Creek, Alaska.

$\mathrm{km}$ long (fig. 2). About $30 \mathrm{~km}$ to the east, in the vicinity of Flume Creek, outcrops of similar ultramafic rock lie on strike with the northern limb. Some small, isolated patches of ultramafic rocks also occur to the east on strike with the southern limb.

During reconnaissance mapping in the Eagle $1: 250,000$ quadrangle, the ultramafic rocks of the Mount Sorenson area in the Eagle quadrangle were examined by H. L. Foster, T. E. C. Keith, S. H. B. Clark, F. R. Weber, and others between 1968 and 1972. The peridotite is located more than $60 \mathrm{~km}$ from the nearest highway and more than $30 \mathrm{~km}$ from a navigable river, so access has been primarily by helicopter. During September and October of 1968, Cache Creek Exploration Co., under the supervision of R. L. Foster, contracted Lockwood, Kessler, and Bartlett, Inc. and made an aerial magnetometer survey along the trend of the Tintina fault in an attempt to delineate ultramafic masses that would present ground targets for asbestos prospecting. A part of that airborne survey covered the Mount Sorenson area, and some of these data are used 

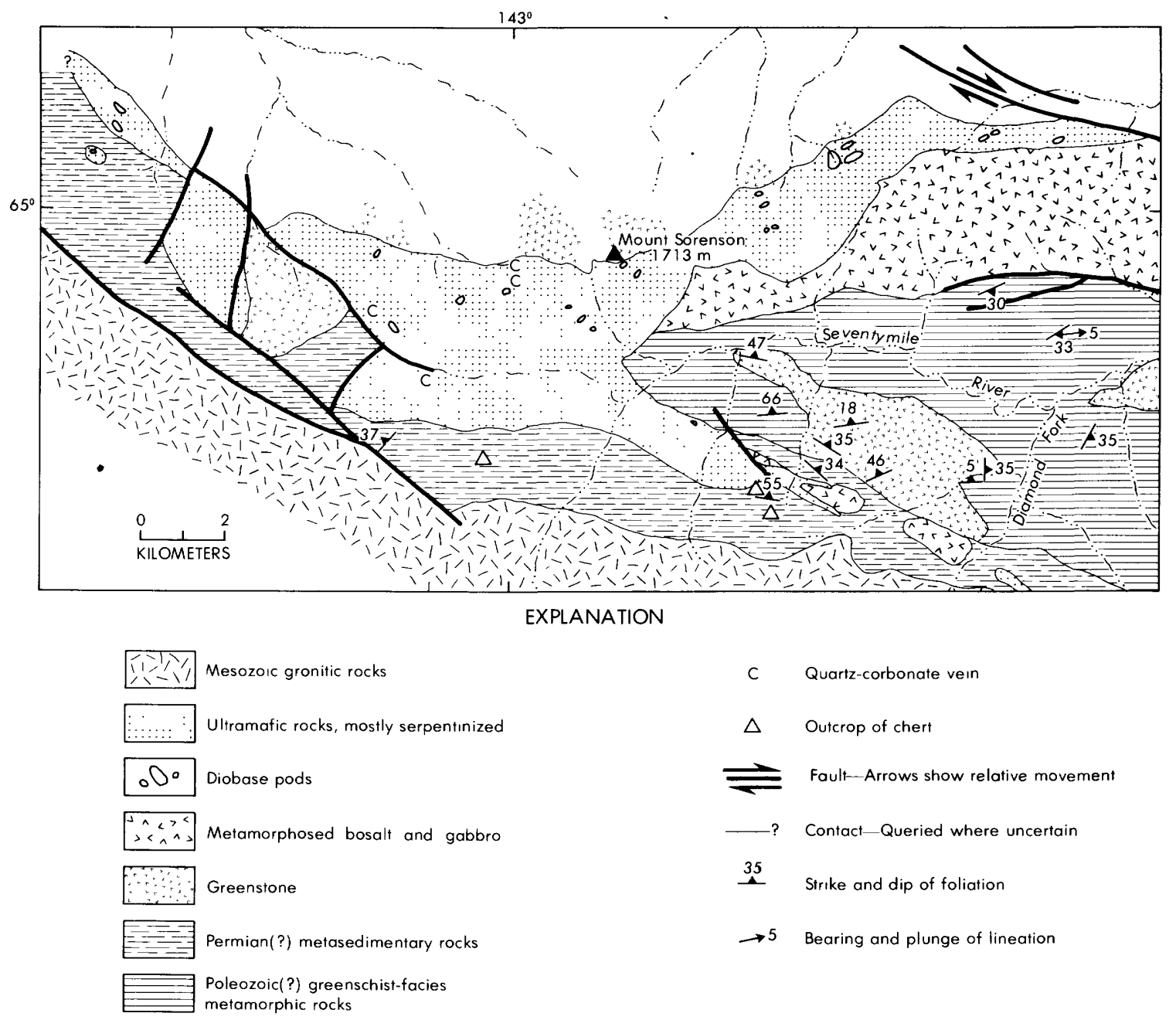

Figure 2.-Geologic map of the peridotite of Mount Sorenson.

in this report. In the summers of 1969 and 1970, Cache Creek Exploration Co. carried out a reconnaissance ground evaluation of several magnetic anomalies and in 1971 managed an exploration program for U.S. Borax and Chemical Corp., during which time E. V. Post, W. L. Lehmbeck, and R. L. Foster prepared a geologic map (unpub., 1:63,360 scale) of the Mount Sorenson area as part of an asbestos and base-metal appraisal project. This work included the parts of the ultramafic body that are in the Charley River quadrangle, as well as parts that are in the Eagle quadrangle.

Information on the ultramafic rocks of the Eagle quadrangle, including those of Mount Sorenson, has been published by Keith and Foster (1973) and Foster and Keith (1974). However, because the peridotite of Mount Sorenson is one of the largest ultramafic bodies in the Yukon-Tanana Upland and has significance in the geologic history of the area, more detailed information is presented here.

\section{PETROLOGY OF THE PERIDOTITE}

The peridotite of Mount Sorenson is composed dominantly of harzburgite with subordinate dunite and minor clinopyroxenite. The eastern part of the body is highly serpentinized dunite containing as much as 5 percent orthopyroxene (or bastite); the western part is dominantly harzburgite, locally containing as much as 35 percent orthopyroxene. The general term peridotite is used for the mass as a whole in accordance with Jackson's (1968, p. 140) classification. The mass is classified according to Jackson and Thayer's (1972) criteria as an alpine-type ultramafic body of the harzburgite subtype.

Nearly all of the peridotite is serpentinized to some extent, but original minerals can generally be distin- 
guished. The peridotite is least serpentinized ( 10 to 25 percent) in the central to western part. In the eastern part of the main mass and in the two limbs 80 to 100 percent of the peridotite is serpentinized.

In outcrop, the peridotite is massive and commonly broken into huge blocks, 6 to $8 \mathrm{~m}$ on a side, bounded by joint surfaces. Most of the blocks have been broken up by intense frost action. Weathered surfaces are typically orange brown and knobby. The knobs are caused by differential weathering of resistant orthopyroxene grains, which generally occur in clots or lenses a few centimeters long. Knobs in the completely serpentinized areas are bastite, a serpentine polymorph after orthopyroxene.

Conspicuous layering of crystals, which is common in most alpine-type peridotites (Loney and others, 1971; Himmelberg and Loney, 1973; Coleman, 1977), occurs in only a few places. Because of the displacement of outcropping blocks by frost action and the paucity of crystal layering, primary mineral foliation can be measured at only a few places.

The unweathered peridotite and serpentinized peridotite are dark green to black and massive, but are commonly cut by tiny ( 1 to $3 \mathrm{~mm}$ thick), irregular, pale-green clinochrysotile veinlets. The amount of serpentinization has little effect on the appearance in outcrop.

Shiny, green, slickensided, and blue-green to black serpentine is common in many places at the boundaries of the mass and in several places within the mass where local shearing has taken place. The serpentine is sheared or broken up into relatively small pieces with curved surfaces. Abundant slip fiber and magnetite specks and streaks are conspicuous on some sheared surfaces.

The rocks in the least serpentinized areas have a coarse- to medium-grained xenoblastic granular texture. The grains appear to have interlocking boundaries, although they are highly fractured and partly serpentinized. Average grain size of olivine crystals is difficult to determine because of the fracturing of grains and serpentinization, but grains generally range from 3 to $6 \mathrm{~mm}$ in diameter. Unaltered grains of orthopyroxene and bastite are 5 to $8 \mathrm{~mm}$ long.

\section{PRIMARY MINERALS}

Olivine is forsterite $\left(\mathrm{Fo}_{80-95}\right)$ as determined optically. Grains are fractured and serpentinized to various degrees, and kink banding is common. In places in the southwestern part of the peridotite body, the fresh olivine grains are granulated as a result of deformation within the peridotite body. The time of granulation relative to the history of the peridotite cannot be determined with present data. However, granulation is more likely to have occurred during mantle deformation than during emplacement into the crust or subsequent crustal folding and faulting, both of which would result in more extensive alteration of the olivine in the granulated area than is observed.
Orthopyroxene is enstatite and generally occurs in clusters of several grains in the fresher (western) part of the peridotite. The distribution of bastite in the serpentinized peridotite of the eastern part of the area indicates that orthopyroxene was present as solitary orthopyroxene grains and was less abundant than in the western part. The grains are commonly bent and strained; their shapes are accentuated by abundant subparallel exsolution lamellae of a reddish-brown opaque mineral, probably ilmenite.

Clinopyroxene is nearly absent in most of the peridotite. In the northwestern area, however, a few layers or lenses are very rich in clinopyroxene. One specimen of equigranular texture consists of about 90 percent clinopyroxene and minor olivine and serpentine minerals. Another specimen from the same vicinity consists of equigranular layers ( 1 to $3 \mathrm{~mm}$ thick) of olivine only and olivine with clinopyroxene.

Chromite in amounts less than 1 percent is disseminated in the least serpentinized peridotite; it is absent in the more serpentinized peridotite. Chromite occurs as small anhedral intergranular grains and as large poikilitic or embayed grains as much as $1.5 \mathrm{~m}$ long. Microscopic alinement of tiny chromite grains forms short, irregular bands usually not more than one grain thick. No megascopic concentrations or layers of chromite were found.

\section{SECONDARY MINERALS}

The massive, dark-green to black serpentine occurring throughout the peridotite is dominantly lizardite as determined by X-ray diffraction. Bastite was $\mathrm{X}$-rayed separately and also is lizardite. Much of the sheared serpentine is a mixture of clinochrysotile and lizardite, and the slip fiber is clinochrysotile. Late crosscutting veinlets (generally about $1 \mathrm{~mm}$ thick) of pale-green serpentine with cross fiber in various stages of development is also clinochrysotile. No antigorite was identified from the peridotite.

In thin section, serpentine fills irregular fractures in primary mineral grains and replaces olivine along fractures and orthopyroxene along cleavages. Mesh texture of serpentine replacing olivine is crudely to well developed in the highly serpentinized parts of the peridotite. These textures are very similar to those described in detail for the Burro Mountain alpine-type ultramafic body in the California Coast Ranges (Coleman and Keith, 1971, p. 314-315).

Magnetite was formed during the serpentinization of olivine and pyroxene. Abundant, tiny, anhedral magnetite grains are concentrated in short, crosscutting microfractures filled with serpentine. In a few places, large anhedral solitary magnetite grains are found, usually in the highly serpentinized areas. Magnetite is not found in the clinochrysotile veinlets.

A slightly red, opaque, elongate, bladelike mineral has exsolved from orthopyroxene parallel to cleavage during serpentization. This mineral has not been positively identified but appears to be ilmenite. 
Brucite is scarce in these rocks but has been identified in a few thin sections and X-ray diffraction traces. Brucite formed during serpentinization along with the magnetite.

Pennite occurs sporadically throughout the peridotite and is moderately abundant in places. In thin section, the penninite is colorless and has anomalous blue and brown birefringence. This mineral is most commonly associated with large anhedral magnetite grains within serpentine, but it also occurs as oriented elongate plates and randomly oriented bundles within the serpentine. Penninite appears to have formed during regional greenschist-facies metamorphism.

Tremolite (having some iron component) has developed from alteration of pyroxenes and in a few places constitutes as much as 10 percent of the peridotite. It is colorless in thin section and occurs as coarse to fine, radiating, fibrous crystals. In places, finegrained talc is associated with tremolite as an alteration product from pyroxene and tremolite. Tremolite and talc occur in a few places but not throughout the peridotite body. These minerals probably developed during regional greenschist-facies metamorphism, although textural evidence is not conclusive.

\section{TECTONIC INCLUISIONS}

Pods of diabase, irregular in size and distribution, are found throughout the peridotite body (fig. 2). The diabase pods are small, $3-20 \mathrm{~m}$ in longest dimension. The diabase is equigranular within the size range of 1 to $2 \mathrm{~mm}$. Subhedral plagioclase originally made up 40 to 65 percent of the diabase, and different proportions of clinopyroxene and hornblende made up the rest of the rock. In thin section, the primary hornblende exhibits pale to strong reddish-brown pleochroism, indicating a high titanium content.

No contact effects between the diabase and peridotite were noted, but the diabase is altered. The diabase is least altered in the main mass of the peridotite where serpentinization is least developed and totally altered in the eastern parts where serpentinization of the peridotite is complete. The plagioclase is altered to fine-grained minerals; clinopyroxene and hornblende are altered to tremolite, penninite, biotite, and magnetite. Skeletal ilmenite crystals surrounded by sphene are common. Biotite is secondary, and its reddish brown color indicates a high titanium content. Altered diabase in the eastern part of the peridotite contains microveinlets of prehnite with associated actinolite and pale-green chlorite. The diabase pods are probably tectonic inclusions that may originally have been diabase dikes. The alteration of the diabase is probably from metasomatism during serpentinization (Coleman,
1967). Tectonic inclusions in a similar environment in the northwestern part of the Yukon-Tanana Upland are described by Foster (1967, p. D120-D122).

\section{QUARTZ-CARBONATE VEINS}

A vertical quartz-carbonate (magnesite and minor dolomite) vein with small patches of bright-green stain cuts through massive peridotite in the north-central part of the mass where the peridotite is little serpentinized. The vein is about $1.1 \mathrm{~m}$ wide and $3 \mathrm{~m}$ long and trends N. $80^{\circ} \mathrm{W}$. The vein is close to but not on the northern boundary of the peridotite and probably is a result of minor hydrothermal activity at some time later than serpentinization and emplacement of the peridotite (Barnes and others, 1973, p. 388-390). Three other similar veins are shown on the map (fig. 2).

\section{PERIDOTITE OF FLUME CREEK}

Thirty kilometers east of Mount Sorenson, a pod of

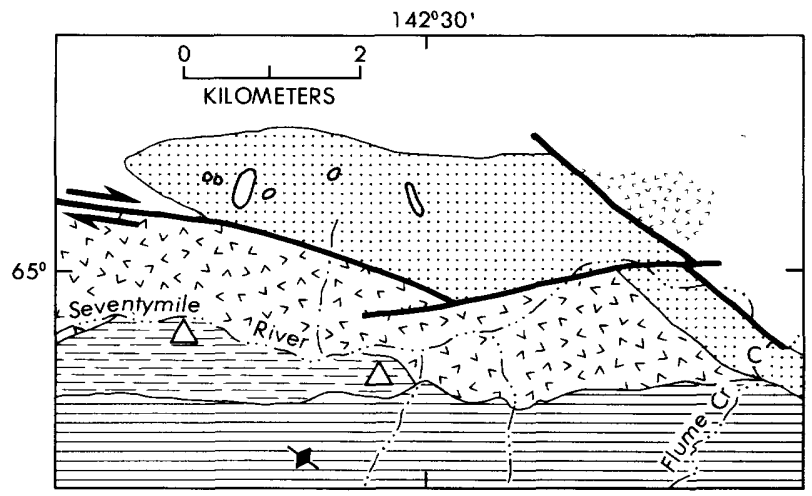

EXPLANATION

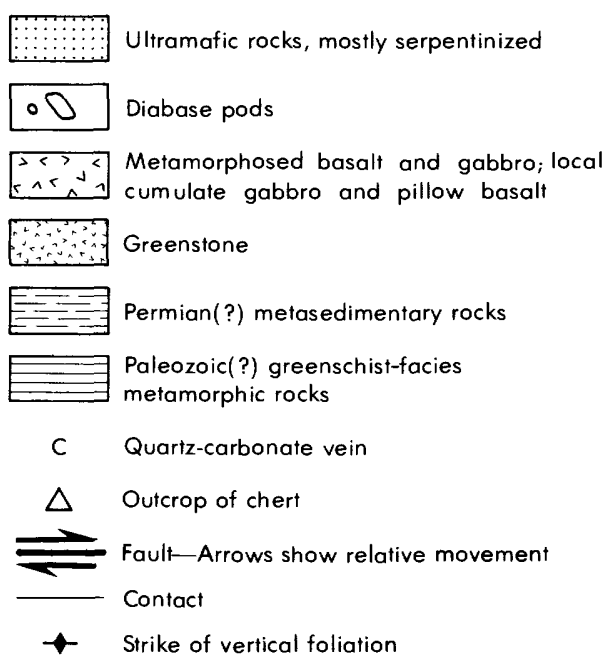

FIGURE 3.-Geologic map of the peridotite of Flume Creek. 
serpentinized peridotite crops out at the mouth of Flume Creek and extends north across the Seventymile River (fig. 3). Part of this peridotite was described as the Flume Creek body (Foster and Keith, 1974, p. 660 ). Petrologic similarities and field relations suggest that the peridotite of Flume Creek may have been part of the peridotite of Mount Sorenson that has been displaced approximtely $11 \mathrm{~km}$ to the southeast along a northwest-trending strike-slip fault (figs. 2 and 3 ).

The dominant rock type of the peridotite of Flume Creek is partly serpentinized harzburgite with less than 10 percent orthopyroxene and no clinopyroxene. The serpentine is composed mostly of lizardite in the mas- sive rock and of clinochrysotile in the later veinlets. Serpentinization of the peridotite to lizardite and clinochrysotile is complete in the Flume Creek area south of the Seventymile River, although bastite indicates that the original rock was harzburgite.

As in the peridotite of Mount Sorenson, several tectonic inclusions of diabase occur in the main part of the peridotite of Flume Creek and a large quartz-carbonate (magnesite-dolomite) zone, $12 \mathrm{~m}$ wide, is exposed along the banks of Flume Creek (Foster and Keith, 1974 , p. 660 ). There are also a few pods of rodingite, which appear from texture to have been gabbro and aphanitic volcanic rocks and now consist of hydrogros-

TABLE 1.-Semiquantitative spectrographic analyses of ultramafic rocks from the serpentinized peridotites of the Mount Sorenson and Flume Creek areas

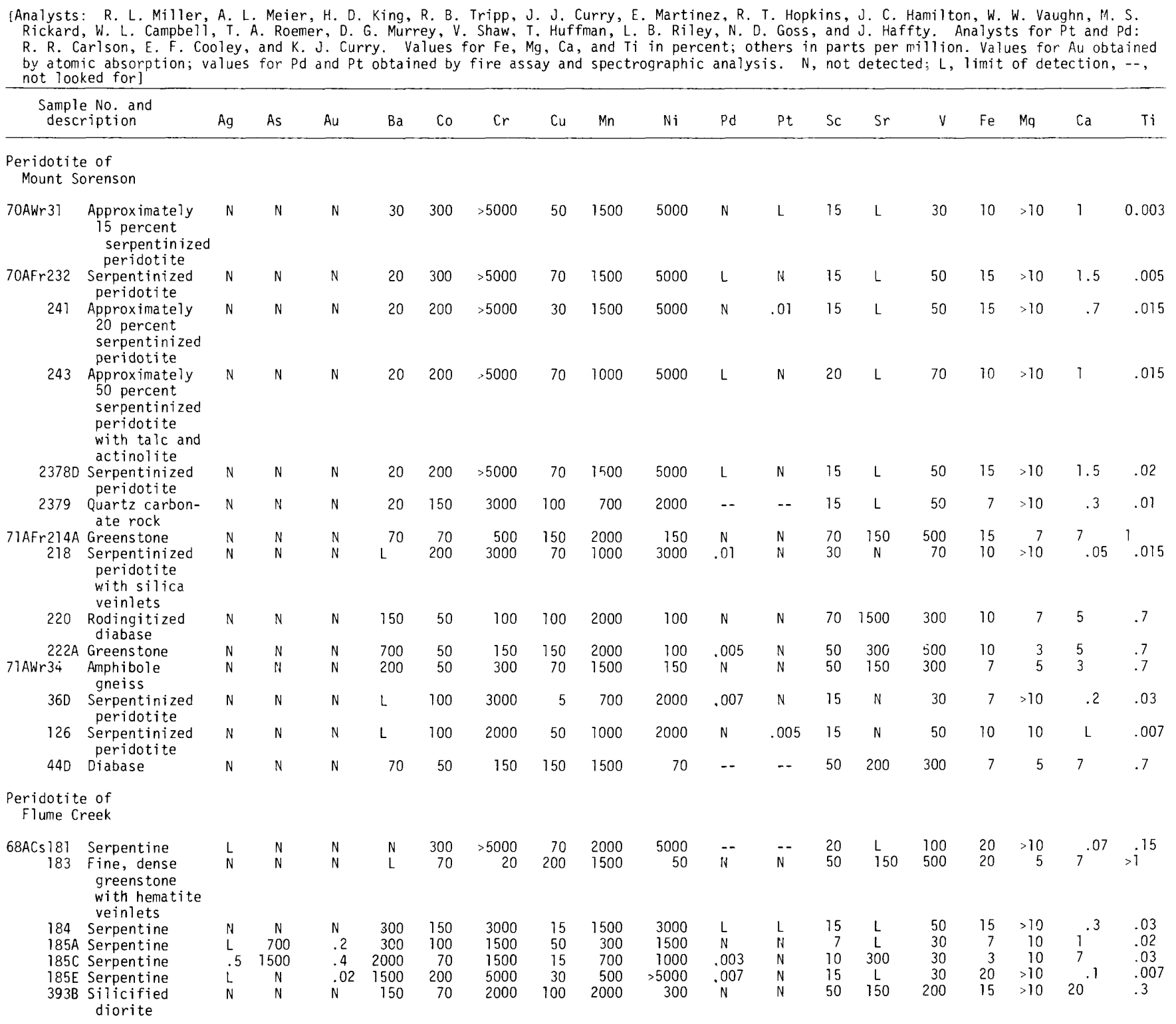


sularite, with subordinate diopside, chlorite, and prehnite. Late crosscutting serpentine veinlets are scarce.

The northern contact of the peridotite of Flume Creek is not exposed because of vegetative cover but may be a fault against metamorphic rocks consisting of greenstone, mica schist, quartzite, phyllite, and some felsic volcanic rocks. At the southern boundary the metamorphic rocks are in contact with a sequence of steeply southward dipping layered cumulate gabbro and pillow basalt with sporadic patches of red chert. Samples were collected to be examined for radiolarians for age determination, but no radiolarians were found (D. L. Jones, oral commun., 1979). Most of the cumulate gabbro consists of rounded orthopyroxene grains that have been partly serpentinized; one layer consists of rounded grains of plagioclase with intergranular clinopyroxene. The cumulate gabbros have not developed any metamorphic fabric from the regional metamorphism of the area. The pillow basalt sequence is probably also dipping to the south, but the pillows are right side up and have no metamorphic fabric. A patch of very fine grained gray to green tuff and chert crops out south of the pillow basalt and probably stratigraphically overlies it, but no contact relations are exposed. The sequence just described south of the peridotite is evidence for an ophiolite, most of which has been faulted and dismembered.

\section{MINOR-ELEMENT DISTRIBUTION}

Semiquantitative spectrographic analyses were done on several samples from the peridotite of Mount Sorenson and the Flume Creek area (table l). The values obtained are comparable to other alpine-type ultramafic rocks (Himmelberg and Loney, 1973, p. 1591; Loney and others, 1971, p. 282-283; Faust and Fahey, 1962). Chromium is consistently high in the Mount Sorenson rocks compared to the Burro Mountain, California (Loney and others, 1971) and Vulcan Peak, Oregon (Himmelberg and Loney, 1973) peridotites, although no concentrations of chromite were found. Only trace amounts of platinum-group elements, similar to those in the Burro Mountain peridotite, have been detected in the peridotites of Mount Sorenson and Flume Creek.

Gold and silver are found in the quartz-carbonate rock associated with the southern serpentinized part of the peridotite of Flume Creek. Clark and Foster (1971, p. 6-10) suggested that placer gold found near the mouth of Flume Creek formerly existed in small amounts in quartz veins and quartz-carbonate rock associated with the serpentine. Lode gold has been found in shear zones at the serpentine contact (Saunders, 1956 ). The association of gold in quartz-carbonate zones adjacent to ultramafic rocks has been reported from the Livengood area of the Yukon-Tanana Upland (Foster, 1968).

\section{ADJACENT ROCKS}

The peridotite of Mount Sorenson and the basalt, gabbro, and greenstone form an ophiolitic sequence that may have been thrust over the metasedimentary rocks (fig. 2). Regional deformation, with associated regional greenschist metamorphism, then produced the present synform and fault system.

The ultramafic rocks are associated with a belt of metamorphic rocks that lies between the Tintina fault system on the north and a large Mesozoic granitic batholith to the south (Foster, 1976). The outcrop pattern of the metamorphic rocks has a northwesterly trend, generally parallel to the Tintina fault and its splays. The limbs of the peridotite of the Mount Sorenson area also generally parallel this trend. In many places the peridotite is in fault contact with the adjacent rocks; in other places the nature of the contact is concealed or otherwise uncertain. The peridotite is faulted internally in several places.

The rocks bordering the peridotite of Mount Sorenson on the north are poorly known but include much massive greenstone of mafic volcanic origin. The rocks that border the northern limb on the south are poorly exposed metamorphosed mafic igneous rocks, mostly basaltic and dioritic. The basaltic rocks are medium to fine grained and locally porphyritic and probably had an original composition of tholeiitic basalt. Scarce pumpellyite and prehnite veinlets are found in places.

Small outcrops of similar metamorphosed basalt occur east of the southeast limb of the peridotite and near the southern part of the peridotite of Flume Creek. A younger basalt outcrop at Alder Creek, a few kilometers east of the peridotite of Flume Creek, appears to be fresh and unmetamorphosed and postdates the greenschist metamorphic terrane.

Much of the area between the limbs of the peridotite consists of a diverse group of greenschist-facies rocks, mostly metasedimentary rocks such as gray, tan, and pink quartzite, quartz-mica schist, and chloritic-quartz schist. Infolded with the quartzite and schist are massive basaltic greenstones that have an outcrop pattern similar to that of the peridotite of Mount Sorenson (east of the area shown in fig. 2, see Foster, 1976). Bordering the southern limb of the peridotite on the south is a narrow band of metasedimentary rocks consisting mostly of fine-grained quartzite, phyllite, metagraywacke, and meta-argillite. A band of similar, but a little less metamorphosed, rocks occurs south of the northern limb. Green and gray chert are also included in this band; no radiolarians have been found in the cherts. These metasedimentary rocks are consi- 
dered to be of Permian age because they are on trend with a faulted quartzite, $13.3 \mathrm{~km}$ southeast of Flume Creek, that contains brachiopods of Permian age (Foster, 1976). The quartzite, quartz-mica schists, and other rocks between the two limbs cannot be dated precisely but are presumed to be of Paleozoic age because of crinoid columnals found in marble layers to the east. Relations of these rocks elsewhere in the Eagle quadrangle suggest that they are older than the Permian rocks.

The only known occurrence of glaucophane schist in the Eagle quadrangle crops out $21 \mathrm{~km}$ southeast of Flume Creek on trend with the Flume Creek body and other small ultramafic masses (Foster, 1976; Foster and Keith, 1974). The rock is medium to fine grained; foliation in outcrop is not obvious but is well developed in thin section. Epidote, glaucophane, and zoisite constitute 70 percent of the rock; albite, garnet, apatite, chlorite, and muscovite are minor minerals; and sphene, chloritoid, hematite, and calcite are accessory minerals. The glaucophane schist has been slightly retrograded, probably during regional greenschist-facies metamorphism, and glaucophane appears to have been partly altered to a blue-green amphibole on some grain boundaries and along some cleavages. The garnets have been partly altered to chloritoid and penninite.
The blueschist outcrop and nearby slivers of serpentinite rest on Paleozoic(?) greenschist-facies metasedimentary rocks (Foster, 1976). Although poor exposures preclude the determination of the relation of the blueschist rocks to the peridotite of Mount Sorenson, the implication can be made that both are parts of a dismembered ophiolite sequence. Blueschist metamorphic rocks are commonly found associated with ophiolite sequences that have been obducted onto continental margins (Coleman, 1977). The blueschist commonly occurs as mélange or tectonic blocks as in the Franciscan Formation of California.

\section{STRUCTURAL RELATIONS}

The Tintina fault system is a major structural break extending northwestward more than $960 \mathrm{~km}$ from the Yukon Territory in Canada (fig. 1) and is probably significant in understanding the emplacement of the ultramafic rocks. The Tintina fault has been postulated to have had $400 \mathrm{~km}$ of right-lateral strike-slip movement (Roddick, 1967, p. 29), but in places vertical displacements have also occurred. In eastern Alaska the Tintina has been active in places as recently as Late Cretaceous or Tertiary time and separates an unmetamorphosed sequence of rocks of the continental margin type on the northeast from metamorphic rocks of several origins on

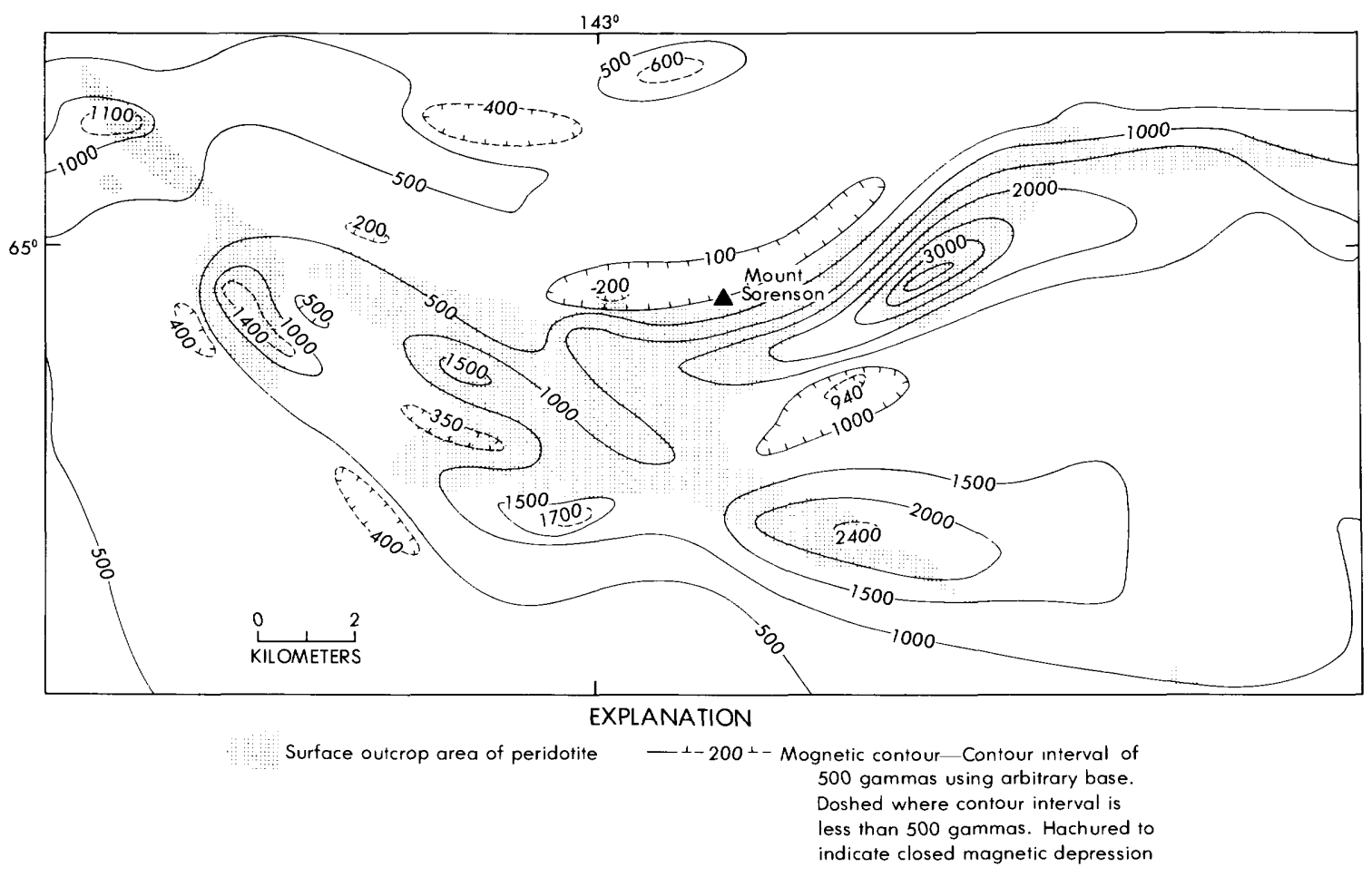

Figure 4.-Aeromagnetic map of Mount Sorenson area. Aeromagnetic data are derived from Alaska Division of Geological and Geophysical Surveys (1972) and from an unpublished aeromagnetic survey for Cache Creek Exploration Co. by Lockwood, Kessler, and Bartlett, Inc. (1968). 
the southwest. The trace of the fault is locally covered in Alaska by Late Cretaceous and (or) Tertiary conglomerate locally interbedded with minor sandstone, shale, and lignite. In the vicinity of Mount Sorenson, there are several northwest-trending faults believed to be splays of the Tintina fault, the largest of which is along the Seventymile River (Foster, 1976). In the vicinity of Mount Sorenson, foliations in the metamorphic rocks and outcrop patterns also have a northwesterly strike.

The major structure of the peridotite of Mount Sorenson and the adjacent rocks that lie between the Tintina fault on the north and the granitic rocks on the south is that of a synform mass with a west-northwesttrending axis. However, the structure is more complex than the reconnaissance mapping shows (Foster, 1976 ), and small faults and folds are abundant. The involvement of the peridotite and greenstones in the synform structure indicates that the area was folded subsequent to the emplacement of the peridotite.

The aeromagnetic map of the area (fig. 4) shows that the surface outcrop pattern of the peridotite of Mount Sorenson conforms fairly closely to the configuration of a magnetic high. Two magnetic highs are opposite each other on the eastern limbs of the peridotite body and are of much higher intensity than that over the less serpentinized main body of the peridotite. Variations in the amount and distribution of secondary magnetite generated during the serpentinization process account for these magnetic anomaly differentials. Maximum aeromagnetic relief on the peridotite of Mount Sorenson is 3,000 gammas (fig. 4); that on the Flume Creek body is 1,100 gammas.

\section{ORIGIN AND GEOLOGIC HISTORY}

The peridotite of Mount Sorenson as characterized in this paper is a typical alpine-type ultramafic body, and it can be further classified as a harzburgite subtype according to the classification of Jackson and Thayer (1972).

The possible origins of peridotite prior to deformation within the mantle have been discussed by Himmelberg and Loney (1973, p. 1596-1597) and Coleman (1977). We assume, in accordance with detailed studies by Loney, Himmelberg, and Coleman (1971, p. 303) and Coleman $(1971 ; 1977)$ on other alpine-type peridotites, that the deformational textures were developed in the mantle.

The peridotite of Mount Sorenson can be considered as part of an ophiolite, probably a dismembered ophiolite, on the basis of the following characteristics:

1. Rock type is predominantly serpentinized harzburgite and some dunite.
2. Slightly metamorphosed basaltic rocks are proximal to Mount Sorenson.

3. Sequence of peridotite, cumulate gabbro, pillow basalt with red chert, and aphanitic volcanic rocks occur along the southern part of the peridotite of Flume Creek.

4. Green- and gray-banded chert crops out in minor amounts in the vicinity of Mount Sorenson and Flume Creek.

5. Fault contacts are common.

6. Diabase is present as tectonic inclusions or dikes that have been deformed (Foster and Keith, 1974, p. $665)$.

The manner of emplacement of the Mount Sorenson and other ultramafic bodies in the Eagle quadrangle was considered by Foster and Keith (1974, p. 665-667). The proximity of the peridotite of Mount Sorenson and many other ultramafic bodies to the Tintina fault strongly suggests that the proposed mantle source of the peridotite could have been derived from a deep crustal suture, possibly a forerunner of the Tintina fault (Churkin and others, 1980). The location of the Tintina fault may also define the approximate ancient margin of the North American plate, possibly in Paleozoic time. Unmetamorphosed rocks to the north of the Tintina fault are characteristic of rocks formed from continental shelf-platform deposits along continental margins (Churkin and others, 1980). However, a large proportion of the metamorphic rocks on the south side of the Tintina fault may also have been derived from continental deposits. Thus, we suggest that the metamorphic rocks south of the Tintina fault are a slice of continental crust or a small plate that has moved northwestward over oceanic crust along the margin of the North American plate. During this movement, postulated to be late Paleozoic time, some oceanic crust and mantle (derived from depth along the suture) were caught up along the suture and locally obducted onto the small continental plate. The occurrence of glaucophane schist in the vicinity of the peridotite is tenuous but supporting evidence for the obduction process (Coleman, 1971; 1977). Serpentinization of the boundaries of the peridotite took place as it was emplaced into the crust and came into contact with meteoric waters.

After initial emplacement, the peridotite masses were broken up and displaced by faulting (including thrusting), slightly metamorphosed, and infolded with the adjacent country rock. This deformation was followed by several hundred kilometers of right-lateral movement along the Tintina fault, probably in Late Cretaceous time (Roddick, 1967, p. 30). Extensive granitic intrusive activity also took place, probably mostly in Late Cretaceous time, as shown by potassium-argon 
dating on a nearby granitic pluton (Foster, 1976). Still later faulting associated with the Tintina fault may have caused minor displacements of the peridotite of Mount Sorenson and displaced the peridotite of Flume Creek.

Alpine-type ultramafic rocks in the Yukon Territory, Canada, which may have a history related to those of the Eagle quadrangle, are discussed by TempelmanKluit $(1976$, p. $1343 ; 1979)$. He postulates that some small alpine-type ultramafic masses in the Yukon were emplaced along steep southwest-dipping faults that represented an Early Triassic interval of movement along the Tintina fault. Tempelman-Kluit (1976, p. 1354) explains the associated basalt, peridotite, and chert in the metamorphic terrane of the Yukon as thrust remnants originating either from the southwest or northeast. He also considers the possibility that the peridotites are an oceanic assemblage derived from a rifted part of the Tintina trench (which was a deep crustal fracture) that was thrust southwestward over the metamorphic terrane when the trench closed (Tempelman-Kluit, 1979, p. 25).

The ophiolitic assemblages of the Yukon, described by Tempelman-Kluit (1976), are more obviously thrust than those at Mount Sorenson since the basal sections are locally exposed. The ophiolitic assemblages of Mount Sorenson and Flume Creek are similar to those along the Tintina fault zone in the Yukon, and hypotheses of emplacement of the ophiolites are comparable, although minor differences in timing and resolution of the direction of thrusting have yet to be worked out. Ophiolite belts are described in other parts of Alaska (Patton and others, 1977) and provide information on the tectonic history of Alaska. The relations of the ophiolitic complex in the Mount Sorenson area to other ophiolite belts in Alaska and Yukon are not clearly understood but may ultimately be significant in unraveling the tectonic history of this part of North America.

\section{REFERENCES CITED}

Alaska Division of Geological and Geophysical Surveys, 1972, Aeromagnetic survey, east Alaska Range, Eagle quadrangle (D-3, D-4, D-5), Alaska: Alaska Division of Geological and Geophysical Aeromagnetic Series.

Barnes, Ivan, O'Neil, J. R., Rapp, J. B., and White, D. E., 1973, Silica-carbonate alteration of serpentine: Wall rock alteration in mercury deposits of the California Coast Ranges: Economic Geology v. 68, p. 388-398.

Churkin, Michael, Jr., Carter, Claire, and Trexler, J. H., Jr., 1980, Collision deformed Paleozoic continental margin of AlaskaFoundation for microplate accretion: Geological Society of America Bulletin, Part I, (in press).
Clark, S. H. B., and Foster, H. L., 1971, Geochemical and geological reconnaissance in the Seventymile River area, Alaska: U.S. Geological Survey Bulletin 1315, 21 p.

Coleman, R. G., 1967, Low temperature reaction zones and alpine ultramafic rocks of California, Oregon, and Washington: U.S. Geological Survey Bulletin 1247, 49 p.

1971, Plate tectonic emplacement of upper mantle peridotites along continental edges: Journal of Geophysical Research, v. 76, p. 1212-1222.

1977, Ophiolites ancient oceanic lithosphere?: New York, Springer-Verlag, $229 \mathrm{p}$.

Coleman, R. G., and Keith, T. E., 1971, A chemical study of serpentinization-Burro Mountain, California: Journal of Petrology, v. 12 , p. $311-328$.

Faust, G. T., and Fahey, J. J., 1962, The serpentine group minerals: U.S. Geological Survey Professional Paper 384-A, 92 p.

Foster, H. L., 1976, Geologic map of the Eagle quadrangle, Alaska: U.S. Geological Survey Miscellaneous Geologic Investigations Map I-922, scale 1:250,000.

Foster, H. L., and Keith, T. E. C., 1974, Ultramafic rocks of the Eagle quadrangle, east-central Alaska: U.S. Geological Survey Journal of Research, v. 2, p. 657-669.

Foster, R. L., 1967, Tectonic inclusions from a serpentinite, eastcentral Alaska in Geological Survey Research 1967: U.S. Geological Survey Professional Paper 575-D, p. D120-D122.

1968, Potential for lode deposits in the Livengood gold placer district, east-central Alaska: U.S. Geological Survey Circular $590,18 \mathrm{p}$.

Himmelberg, G. R., and Loney, R. A., 1973, Petrology of the Vulcan Peak alpine-type peridotite, southwestern Oregon: Geological Society of America Bulletin, v. 83, p. 1585-1600.

Jackson, E. D., 1968, The character of the lower crust and upper mantle beneath the Hawaiian Islands: International Geological Congress, 23d, Prague 1968, Proceedings Section 1, Upper mantle (geological processes): Prague, Academia, p. 135-150.

Jackson, E. D., and Thayer, T. P., 1972, Some criteria for distinguishing between stratiform, concentric and alpine peridotite-gabbro complex: International Geological Congress, 24th, Montreal 1972, section 2, p. 289-296.

Keith, T. E. C., and Foster, H. L., 1973, Basic data on ultramafic rocks of the Eagle quadrangle, east-central Alaska: U.S. Geological Survey Open-File Report 73-140, 4 sheets.

Loney, R. A. Himmelberg, G. R., and Coleman, R. G., 1971, Structure and petrology of the alpine-type peridotite at Burro Mountain, California, U.S.A.: Journal of Petrology, v. 12, p. 245-309.

Patton, W. W., Jr., Tailleur I. L., Brosgé, W. P., and Lanphere, M. A., 1977, Preliminary report on the ophiolites of northern and western Alaska, in Coleman, R. G., and Irwin, W. P., eds., North American ophiolites: State of Oregon, Department of Geology and Mineral Industries Bulletin 95, p. 51-57.

Roddick, J. A., 1967, Tintina trench: Journal of Geology, v. 75, no. 1, p. 23-33.

Saunders, R. H., 1956, Report on the Flume Creek lode-gold prospects, Eagle quadrangle: Alaska Territories Department of Mines Open-File Report, 7 p.

Tempelman-Kluit, D. J., 1976, The Yukon crystalline terrane : Enigma in Canadian Cordillera: Geological Society of America Bulletin, v. 87, p. 1343-1357.

1979, Transported cataclasite, ophiolite, and granodiorite in Yukon: Evidence of arc-continent collision: Geological Survey of Canada Paper 79-14, $27 \mathrm{p}$. 